\title{
Doing Business in Moldova. Case Study: Analysis of the Agri-food Sector
}

\author{
Mihaela Munteanu Pila \\ mihaela.pila@ugal.ro \\ Silvius Stanciu \\ sstanciu@,ugal.ro \\ Dunarea de Jos University of Galati, Romania
}

\begin{abstract}
This paper aims to highlight the importance of developing a profitable business, increasing economic competitiveness and creating jobs in the Republic of Moldova. The creation and consolidation of a business is based on a series of objectives that allow the selection and implementation of the most appropriate interested parties strategies across the organization, society and the economic environment. Through this research, based on data provided by the World Bank and the National Statistical Commission, an analysis of the business development strategies in the Republic of Moldova is proposed for the development of the economic sector. Following the analysis, it has been found that Moldova has made substantial progress in facilitating the creation of new businesses with a positive impact on the growth of small companies, including in the agri-food sector. The results are useful for developing a comprehensive analysis of the impact of governmental economic measures on the agrifood related businesses.
\end{abstract}

Keywords: Business, development, fishery.

JEL code: L22, Q12

\section{Introduction}

The opportunity to develop a business creates a purpose and can provide a higher degree of financial comfort for the population of the Republic of Moldova. The World Bank's Doing Business Annual Report analyses the power of a simple idea with the supporting environment of the World Bank through property registration and implementation of contracts that is vital to promoting entrepreneurship. Despite the decrease in the World Bank's base rate, loans remain expensive and so many companies are on the verge of bankruptcy. The original purpose is to provide an objective basis for understanding and improving the regulatory environment for businesses around the world. The Republic of Moldova has climbed eight positions over the last two years concerning the business environment. In accordance to" Doing Business 2017” Report and World-Class Business Rankings, Moldova is on the 44th place in the world and on the 11th in Europe. The statistical reports of the Republic of Moldova, drawn up by the economic operators from Chisinau for the period of 2013-2015, show general data about the current state of the fishery activity, state and quality of the environment, labour market, industry, agriculture, construction, transport, trade and financial results of the economic operators.

\section{Short literature review}

The Republic of Moldova is one of the countries covered by the FAO Regional Initiative, regarding the development of family farms and the empowerment of small farmers for improving the living standards. Therefore, several projects and activities related to the promotion, monitoring and rural development as well as supporting integrated community development at the local level (Ministry of Agriculture, Regional Development and Environment, 2018) have been implemented. There is a need for the continuous development of the market infrastructure and its orientation towards improved access to information, banking sources and Statistics, 2009). 
The possibility to develop a business is crucial for each country, with the aim of opening up new opportunities, and providing long-term financial stability, preventing poverty. For achieving good results, it is required knowledge in the field and a team of skilled and qualified staff (Doing Business, 2017). The foreign direct investments, performed in a transparent manner and for long enough periods of time, represent a motor for the development of national economies, but in Eastern Europe they are still quite small (Stanciu, 2016). The improvement of the entrepreneurial regulatory system must be based on a special investment system that will allow the identification of real problems in starting a business and will facilitate the need of opinion support on the measures proposed by the State in achieving the positive effect for own realization (National Bureau of Statistics, 2009). In Central and Eastern Europe Countries, Agriculture, Food processing and Food retail are characterized by different percentages of foreign investment (Stanciu, 2014).

\section{Material and method}

The information on the facility to start up a business was collected from the Doing Business Reports carried out by the World Bank (2014-2018). Data on the number of functional companies in the Republic of Moldova were selected from the database of the National Bureau of Statistics (2009-2017), the official communications of the Ministry of Finance, IDNO.md, from economic operators and other state and non-governmental institutions. For the legislative area, the State Register of Legal Documents of the Republic of Moldova was used. The collected data were statistically analysed and sequenced. The results obtained were compared with other literature data for an appropriate interpretation.

\section{Objectives and dynamics of improving the business environment in the Republic of Moldova}

The basic objectives of the entrepreneurial policy are aimed at:

- supporting young entrepreneurs in launching a business in the country;

- stimulating migrant people to start a business in the Republic of Moldova;

- business development regardless of gender;

- expanding support infrastructure for business by developing incubators and industrial parks. According to the World Bank's, the reduction of the business start-up costs, the exclusion of the obligation to provide information relating to social charges on paper, the simpler execution of contracts, the simplification of the power grids connecting process, have led to an improvement in the business environment (figure 1).

Figure 1. 'Doing Business" Score and Rank position for Republic of Moldova

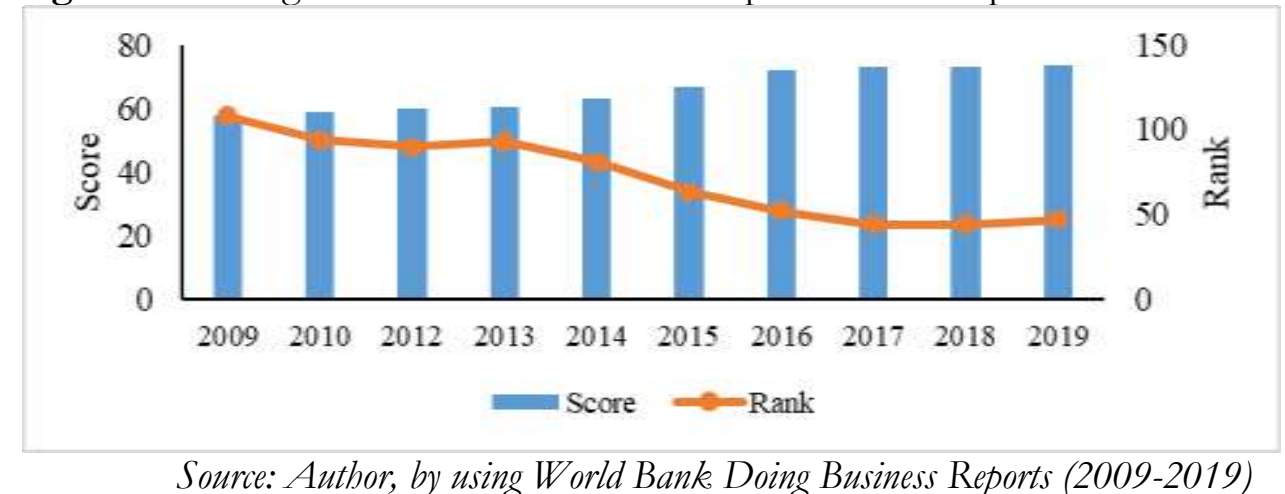

Therefore, according to the previous reports from 2013-2018, it is noticed that the Republic of Moldova climbed from position 82 in 2013 to position 44 in 2018, which shows that the business environment has gotten better and the conditions for developing a business have significantly improved. 


\section{Economic profile of the Republic of Moldova for business start-up}

Law No. 179 of 21.07.2016 lays down state support measures for the creation and development of performances in the Republic of Moldova. The purpose of this law is to promote the sustainable development of micro, small and medium-sized enterprises by improving the economic environment. The structure of the entrepreneurship in RM, by company category, is presented in Figure 2.

Figure 2. Structure of the business environment in RM, by company category (2017)

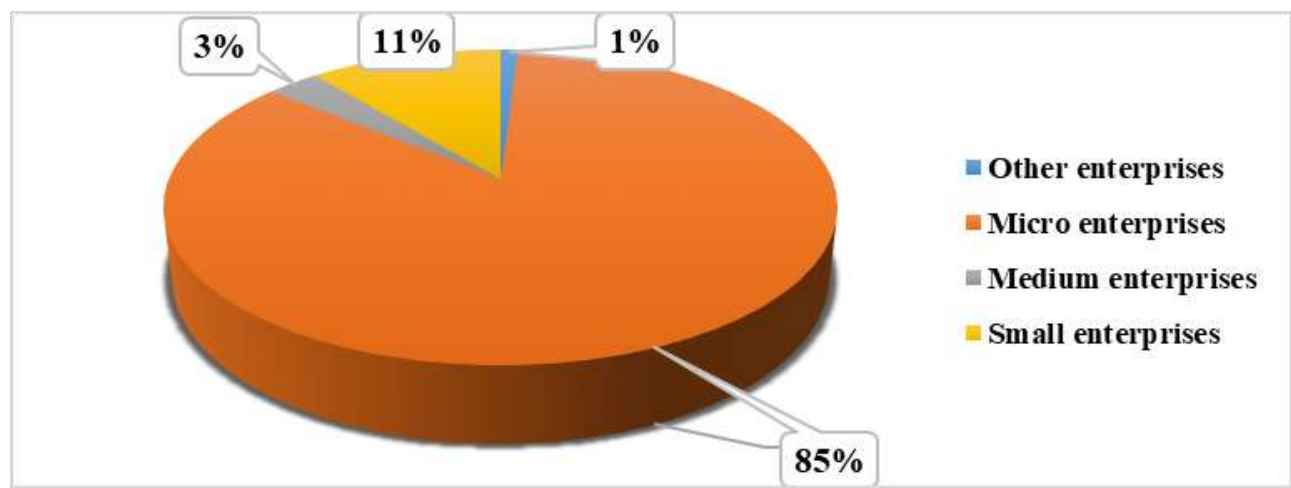

Source: Authors, Data processed by the National Burean of Statistics (2019)

According to the data presented, micro enterprises with a maximum of 9 employees and an annual turnover of up to 9 million MDL (or with total assets of up to 9 million MDL); represent more than $85 \%$ of the companies registered in the year 2017 in the Republic, providing jobs to about 107.8 persons, total revenues of over 36,178.7 million MDL and a profit of over 3,434.4 million MDL. The share of enterprises in Agriculture, Forestry and Fishery sector in the Republic of Moldova is represented in Figure 3. The most frequent enterprises are the micro enterprises representing more than $2.9 \%$ of total. The distribution of entrepreneurs is given by the location of the enterprise, by analyzing the development region in the rural area and in the urban area (North, Center, Chisinau, South, and ATU Găgăuzia). Most of the entrepreneurs lives in Chisinau City (58.7\%).

Figure 3. Business enterprise in Sector Agriculture, forestry and fishery.

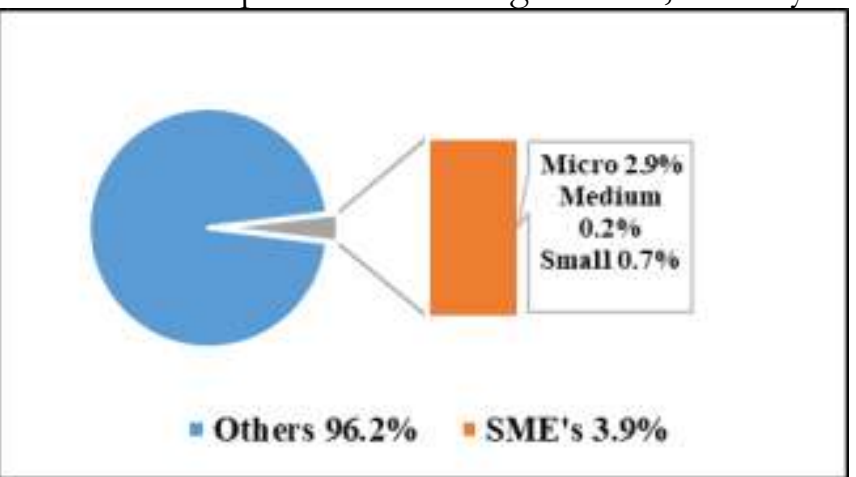

Source: Authors, Data processed by the National Burean of Statistics (2019).

For the other development regions of the Republic of Moldova, more respondents are active in the North Region (17.1\%), Center (14.0\%), South (6.9\%), (3.3\%) UTA Găgăuzia. There were not observed significant gender differences regarding the regional aspect. Only in Chisinau the share of female entrepreneurs is higher than that of men by $1.4 \%$. While in the Center of the Republic of Moldova the share of women is lower than that of male entrepreneurs by $1.4 \%$ (figure 4 ). 
Figure 4. Entrepreneurs by Regions in Republic of Moldova

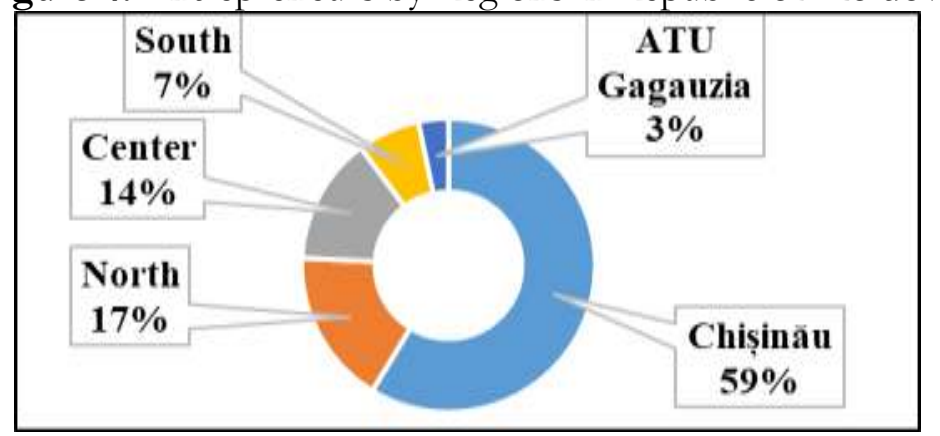

Source: Authors, by using National Bureau of Statistics (2019)

The distribution of the categories of entrepreneurs by sex, by development regions in Moldova, is presented in Figure 5.

Figure 5. Male (a) and female (b)antrepreneurs by Moldavian regions

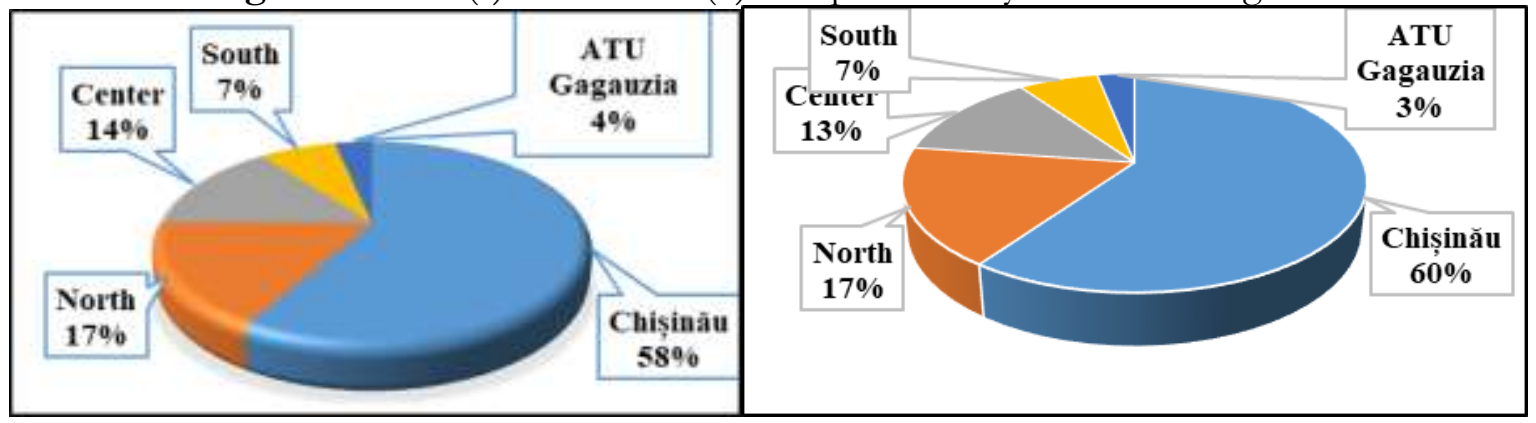

a)

Source: Authors, by using National Burean of Statistics (2019)

The largest share of the main type of activity in the Republic of Moldova is held by the wholesale and retail trade, restaurants and hotels (46.8\%), women being more entrepreneurial in this kind of business. Correspondingly, men more often start business in industry $(15.9 \%)$ and agriculture, hunting, forestry and fishery. In Chisinau City the share of women exceeds the men by $2 \%$. In the Central region against the share of women in entrepreneurship is lower than for men by $1.4 \%$. Agriculture, hunting, forestry and fishery are more developed in the southern region of the Republic of Moldova, representing $17.7 \%$. In Chisinau this type of activity is less developed and represents a share of $0.9 \%$ (figure 6 ).

Figure 6. Agriculture, Forestry and Fishery Sector in Moldova, by Regions

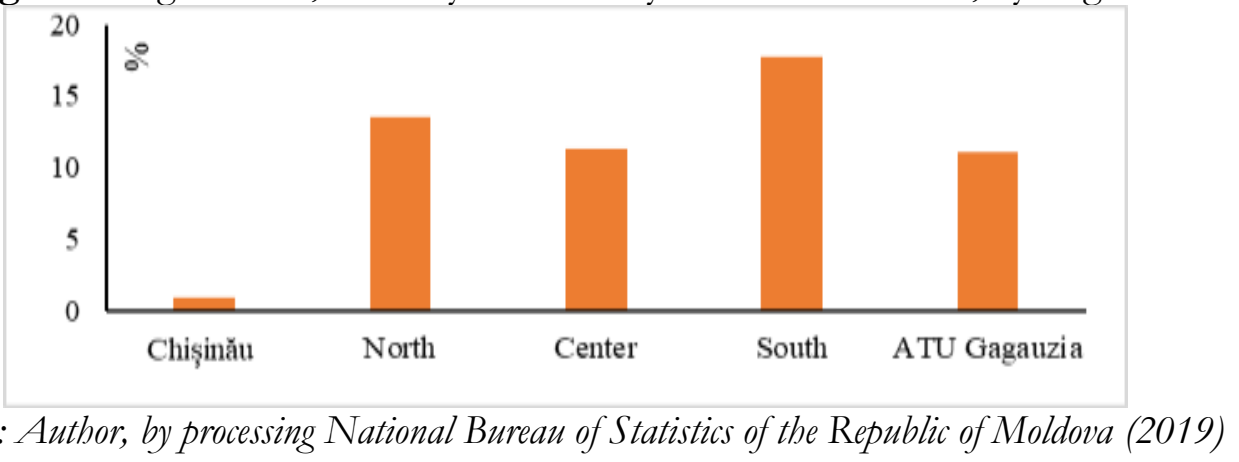

Thus the analysis of the distribution of enterprises by types of activities showed that in the agriculture sector, the highest share is held by the enterprises from the North, Centre and South region of the Republic of Moldova. The entrepreneurial analysis by development regions highlighted the following: most of the owners live/operate in Chisinau (outside the forestry and 
aquaculture business). A relatively large proportion of entrepreneurs are active in the North and Central Region of the Republic of Moldova. In the South, agriculture, forestry and fishing holdings account for the highest share of $17.7 \%$, compared with $7 \%$, the average per development region.

\section{Conclusion}

The Republic of Moldova is a country that has available natural resources to develop the fishery industry. The current statistical data show that, at the moment, fishery is a less developed branch in the Republic of Moldova, which can be a positive factor for many young entrepreneurs for developing a well-established farm. Entrepreneurship should be promoted through courage, experience and absorption of the most advantageous funds in order to develop the fishery sector in the Republic of Moldova in both positive and less developed regions. In different regions of the Republic of Moldova, the local administrative bodies can offer to various groups of entrepreneurs, the more attractive condition for business development. According to the data, the Republic of Moldova can be an active member of the Eastern Partnership to promote a deep political association and economic integration with the European Union by encouraging governments to initiate and facilitate the country's development process.

Acknowledgments: „This work is supported by the project ANTREPRENORDOC, in the framework of Human Resources Development Operational Programme 2014-2020, financed from the European Social Fund under the contract number 36355/23.05.2019 HRD OP /380/6/13 - SMIS Code: 123847."

\section{References}

National Bureau of Statistics (2019), Activitatea interprinderilor mici și mijlocii, [online], [accessed 26.04.2019], http:/ / wmw.statistica.md/ category.php? l= roevidc=368.

Doing Business, (2017), Equal opportunity for all, A world bank, group flagship report, [online]. [accessed 26.03.2019], bttp:// www.doingbusiness.org/content/dam/doingBusiness/media/ Annual-

Reports/English/DB17-Report.pdf.

Doing Business, (2019), Training for reform, A world bank group flagship report, Moldova, [online]. [accessed 28.03.2018], bttp:// mww.doingbusiness.org/content/dam/doingBusiness/country/m/moldova/MDA.pdf

Ganescu, M. C., (2012), Responsabilitatea socială a intreprinderii ca strategie de creare și consolidare a unor afaceri sustenabile, Pitesti, [online]. [accessed 28.03.2018], http:/ / store.ectap.ro/articole/799_ro.pdf

Guvernul Republicii Moldova, (2007), Informație generală despre Proiectele UE în Moldova, [online]. [accesed 27.03.2018], bttps://gov.md/europa/ro/content/informa\%C5\%A3ie-general\%C4\%83-despre-proiectele-ue$\%$ C3\% AEn-moldova

Guvernul Republicii Moldova, (2016), Lege Nr 179 cu privire la interprinderile mici și mijlocii, [online]. [accessed 27.03.2018], http:/ / lex.justice.md/md/366638/

Ministerul Agriculturii și Dęvoltării Regionale și Mediului, (2018), Moldova și FAO au inițiat procesul de suport pentru dezvoltarea comunitară integrată, online]. [accesed 28.03.2018], http:/ / www.madrm.gov.md/ ro/ content/ moldova-\%C8\%99i-fao-au-ini\%C8\%9Biat-procesul-de-suport-pentrudezvoltarea-comunitar $\%$ C4\%83-integrat $\% C 4 \% 83$.

Stanciu, S., 2014, The Romanian Food Sector Attractiveness for Foreign Investment, SEA-Practical Application of Science, 5(2): 603-610.

Stanciu, S., 2016, The Foreign Direct Investment in The Romanian Agrifood Production, SEA-Practical Application of Science, 2(11): 289-207.

Statistica Moldovei, (2016), Chișinău in cifre anuar statistic 2015, [online]. [accessed 27.03.2018], http:// wnw.statistica.md/public/files/publicatii_electronice/Chisinau/Anuar_Chisinau_2016.pdf

Statistica Moldovei (2009), Condițiile de creare și dezvoltare a interprinderilor, [online]. [accessed 26.03.2019], bttp:// wnw.statistica.md/public/files/publicatii_electronice/conditii_intreprinderi/Conditii_creare_intreprinderi _ro.pdf 